\title{
原著
}

\section{施設入所精神発達遅滞者の齲蝕罹患に 関する経年疫学研究}

一入所時所見について その 2-

\author{
A Long-Term Epidemiological Study of Dental \\ Caries Prevalence in Institutionalized \\ Mentally Retarded Individuals \\ -Findings at Admission II- \\ 小黒章* 堀井欣 - * \\ Akira OGURO* and Kin-ichi HORII*
}

Received January 8, 1990 ; accepted February 1, 1990

\begin{abstract}
Epidemiological analyses were performed on the prevalence of dental caries among the 1107 subjects at the time they were admitted to the Niigata Prefectural Institute of Total Traning for the Mentally Retarded, Colony Niigata Shiroiwa-no-Sato, during the years 1971-1988. Statistical analyses were done using a data base which was constructed from examination records in which caries was graded according to the four-grade diagnostic standard.

(1) The tooth DMF rate was $22.0-31.4 \%$ for the 15-19-year-old age groups for the periods 1971-1975, 1976-1981 and 1982-1988, and was calculated to reach more than $50 \%$ at the end of the subjects' $40 \mathrm{~s}$ for the period 1982-1988, gradually increasing with age and time. Changes in the tooth mortality rate and the tooth fatality rate due to dental caries in all subjects in their $30 \mathrm{~s}$ were 18.1, 26.1, and $27.8 \%$, and $51.7,62.6$, and $53.6 \%$, respectively, for the periods $1971-1975,1976-1981$, and 1982-1988. The changes in these two indices in the 15-19-year-olds were on the decrease: $6.0,4.5$, and $3.1 \%$, and $23.1,16.8$, and $11.7 \%$, respectively. The treated tooth rate and the restorative index were designated for all the age groups on the basis of the values determined for the 15-19-year-old group. These were $8.9,15.2$, and $16.8 \%$, and $41.8,62.2$, and $69.9 \%$ in $1971-1975,1976-1981$, and 1982-1988, respectively.

In comparison to the averages of all Japanese, the rate of tooth loss was higher among our subjects up to the present. As a result, the rate of tooth treatment is proportionally diminished. There was not a great difference in the rate of occurrence of dental caries.

(2) Though there was a considerable difference between males and females in dental caries prevalence in 1971-1975, it disappeared in 1982-1988, showing early signs of fading in 1976-1981.
\end{abstract}

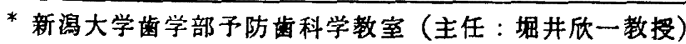

* Department of Preventive Dentistry Niigata University School of Dentistry (Director: Prof. Kin. ichi HORII) 
(3) There was no difference in dental caries prevalence between the profound to severely retarded and the moderately retarded who could be institutionalized. Even when the degree of mental retardation influenced dental caries prevalence it played a role that was less influential than that of dental care service; it did not directly correlate with cavity formation.

(4) The Occurrence of dental caries showed no fluctuation in females and was on a very gradual increase in males in these 17 years. The rate of treated cavities rapidly increased. Therefore, there was a corresponding decrease in untreated and lost teeth.

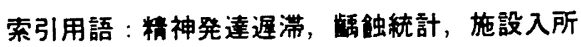

Koy words: Mental retardation, Dental caries prevalence, Institutionalized

\section{緒言}

精神発達遅滞者の能蝕稚患に関する疫学研究は早くか ら行われ，多くの報告がみられるが，触をを表す指標の 示す値を正常者と比較した時，どの水準にあるかは評価 が一定しない1-3)。これは, 精神発達遅滞の程度とかその 病因, 画口清掃の状態（能力）その他の要因が触の発 生と進行に複雑な影響を及ほすことに因るものとされて きた1-3)。したがって精神発達遅滞者の蝕䍜患を疫学 的に考える場合，これらの諸因子に言及することが必要 となる。さらに本邦では養護学校4,5), 入所療育施設とし ての病院 ${ }^{6-8)}$ における調查研究が多く，16歳以上の精神 発達遅滞者に関して激触䍜患を疫学的に論ずるに必要な 情報量を満たしていると言えない。

新潟県精神薄弱者総合援護施設「コロニーにいがた白 岩の里」は1971年に創設され, 同時に齿科診療室が設固 された。定期 (春乎) 歯科検診所見をもとに診療がすす められる一方, 保存されていた検診記録から入所者の歯 科所見データベースが作成された。著者らは，このデー タペースを用いて成人層を含む幅広い年龄構成の精神発 達遅滞者に関する淿触䍜患の疫学的特性を探る意図のも とに解析を進め, 先ず, 厚生省の歯科疾患実热調查報告 を対照として比較結果を報告したの。。それに関する追加 所見とさらに上述の要因を念頭において群内比較から得 られた所見を報告したい。

\section{研究対象と方法}

\section{1. 研究対象と検診方法}

1971年夏から88年春までの間にコロニーにいがた白岩 の里に入所した1107名の精神発達遅滞者を対象とし, 入 所時の年龄分布, IQ 分布など, この集団の性格に関す る資料の一部はすでに報告したとおりである97。対象は 新潟県の重・最重度精神薄弱者の $9-14 \%$ と中等度精神薄
弱者の 8-12\%を占めるものと推定される。IQ 判定は ビネー式によっている。

4 度分類の齗触検出基準に従って，智歯を除く全永久 荘を対象とし人工照明下で視診，歯面単位で記録した。 1971-80年の問，1名が入所時歯科検診を担当し，81年 からもう1名が加わった。充分に歯科検診介助の経跧の ある看護婦 3 名が記録にあたった。そのほか検診基準の 細部, 検診器具, 検診票などについては報告のとおりで ある

2.コンピュータ処理による統計解析

$\mathrm{C}_{1}, \mathrm{C}_{2}, \mathrm{C}_{3}$ を Dとし, $\mathrm{C}_{4}$, 亦失歯を $\mathrm{M}$, 修復歯を $\mathrm{F}$ として処理した。被検者数の不足と創設期の入所年度に よる IQ の偏りを同時に補う意味において，各年度の新 規入所者の一人平均被検歯数, DMFT 指数の変動に対 し年度較差に対する 分散分析の後，入所年度により 7175，78-81，82-88年の3 期に分けて統計処理を行った9”。

DMFT 指数とその各成分, DT, MT, FT 指数, 及 び DMF 歯率と Tooth mortality rate (以下, TMR と略), Tooth fatality rate by dental caries (以下,

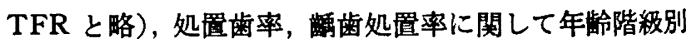
に $\mathrm{t}$ 值を求め，MR/SMR 比による比較を行った。 $M R$ (平均比) $=\Sigma \mathrm{t} / \mathrm{K}$ ( $\mathrm{K}: \mathrm{t}$ 值を算出した級の数), SMR $(M R$ の標準誤差 $)=(\mathrm{k}-1)^{-0.5}$ により計算される(0)。ま た,

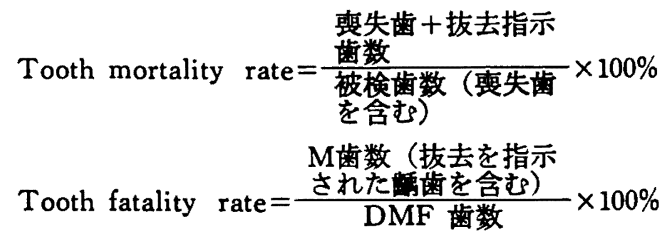

処置苗率 $=\frac{\text { 現在歯中の処置歯数 }}{\text { 現在齿数 }} \times 100 \%$

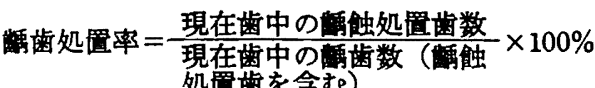


である。龇歯処圈率は Restorative index とも称す る11。年㱓区分は WHO の蔗めるところによった ${ }^{12) 。 ~}$

\section{結 果}

1. DMF 歯率および歯科疾患実態調查との比較

入所年度により 3 期に分けて DMF 歯率とそれに関 連する指数, TMR, TFR, 処固歯率, 婳药処置率を Table 1-1, -2, -3 に示す。6-14歳の入所者は少なく, 一群にまとめた。DMF 歯率は15-19歳では22.0-31.4\% であり，增齡的に，また，入所年度を経るごとに漸增の 後，82-88年では40代終わりに50\%を越すと思われる。 TMR, TFR は増龄的には溸增傾向はあるが，年度を経 るごとに逆に漸減傾向を示し若年層ほど明かである。す なわち，71-75，76-81，82-88年における30歳代（合計） の推移は各々，TMR に関して，18.1，26.1，27.8\%， TFR に関して51.7，62.6，53.6\%であるが15-19歳（合 計）のそれは前者について $6.0,4.5,3.1 \%$, 後者につい て23.1，16.3，11.7\%と減少している。処置歯率，属歯 処圈率は各年龄層を通しほぼ一定し，入所年度を経るご とに僅かずつ向上する感があると同時にその場合，むし ろ増龄的に処置歯率は溸減傾向にあるように見える。 15-19歳（合計）の値が全体をよく代表し， 3 期別年代 順に処置歯率，歯処固率は各々，8.9，15.2，16.8\%
および $41.8,62.2,69.9 \%$ である。

これらの諸指数を厚生省の歯科疾患実態調查報告を対 照として MR/S DMF 歯率は男では71-75年にのみ低く後は差がない。 女では最初差がなく，その後次第に入所者が低くなる。 他の 4 指数に比へ $M R / S_{N R}$ 比の絶対値は低い。TMR, TFR は男女とも多少の变動を示しながら，入所者がか なり高值である。処圆歯率，殥歯処圈率は男女とも7175年には圧倒的な差があるが，急速に改善し82-88 年に は男の鹤歯処固率の差は解消している。71-75 年の対照 には昭和50年 ${ }^{19)}, 76-81,82-88$ 年の対照には昭和56年 ${ }^{14}$ の報告の值をそれぞれ用い，20歳以上の年齢階級に関し ては加重平均を算出した。なお，年龄，性別区分の結果 被検者数 5 以下となる群では $\mathrm{t}$-値を算出しなかった。以

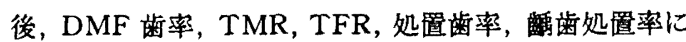
関する MR/S MR 比算出では全てこのようにした。

2. DMFT 指数, DMF 歯率に関する男女比較

DMFT 指数とその各成分, DMF 齿率とそれに関連 する指数について男女比較を行った。なお，DMFT 指 数とその各成分 DT, MT, FT 指数については前報告9 の Table 4-1, -2, -3 を参照されたい。DMFT 指数は 71-75年には統計学的に高度な有意差がみられるが(女> 男)，82-88年には解消している。76-81年では MT 指数

Table 1-1 Tooth DMF rates of newcomers in 1971 through 1975

\begin{tabular}{lllcccccc}
\hline $\begin{array}{c}\text { Age } \\
\text { Years) }\end{array}$ & Sex & $\begin{array}{c}\text { N } \\
\text { (Av.age) }\end{array}$ & $\begin{array}{c}\text { Personal } \\
\text { DMF } \\
\text { rate }(\%)\end{array}$ & $\begin{array}{c}\text { Tooth } \\
\text { DMF } \\
\text { rate }(\%)\end{array}$ & $\begin{array}{c}\text { Tooth } \\
\text { mortality } \\
\text { rate }(\%)\end{array}$ & $\begin{array}{c}\text { Tooth } \\
\text { fatality } \\
\text { rate }(\%)\end{array}$ & $\begin{array}{c}\text { Treated } \\
\text { tooth } \\
\text { rate }(\%)\end{array}$ & $\begin{array}{c}\text { Restora- } \\
\text { tive } \\
\text { index }\end{array}$ \\
\hline \multirow{2}{*}{$6-14$} & Males & $27(11.3)$ & 77.8 & 20.9 & 8.3 & 39.6 & 0.0 & 0.0 \\
& Females & $32(10.1)$ & 87.5 & 30.7 & 8.6 & 27.9 & 0.6 & 2.3 \\
& Total & $59(10.6)$ & 83.1 & 26.1 & 8.4 & 32.3 & 0.3 & 1.5 \\
\hline $15-19$ & Males & $138(17.3)$ & 94.9 & 22.0 & 4.9 & 22.3 & 6.8 & 37.7 \\
& Females & $107(17.6)$ & 98.1 & 31.1 & 7.4 & 23.8 & 11.7 & 45.7 \\
& Total & $245(17.4)$ & 96.3 & 26.0 & 6.0 & 23.1 & 8.9 & 41.8 \\
\hline $20-24$ & Males & $56(21.7)$ & 96.4 & 29.7 & 9.4 & 31.7 & 6.4 & 28.4 \\
& Females & $67(21.5)$ & 98.5 & 39.3 & 16.2 & 41.3 & 9.6 & 35.0 \\
& Total & $123(21.6)$ & 97.5 & 34.9 & 13.1 & 37.6 & 8.1 & 32.2 \\
\hline $25-29$ & Males & $32(26.7)$ & 90.6 & 34.4 & 12.5 & 36.4 & 8.3 & 33.3 \\
& Females & $39(26.9)$ & 94.9 & 41.9 & 18.2 & 43.4 & 6.2 & 21.3 \\
& Total & $71(26.8)$ & 93.0 & 38.6 & 15.7 & 40.6 & 7.2 & 26.4 \\
\hline $30-39$ & Males & $15(33.1)$ & 93.3 & 14.6 & 5.5 & 37.7 & 4.3 & 44.7 \\
& Females & $21(33.5)$ & 100.0 & 49.7 & 27.2 & 54.7 & 11.4 & 36.9 \\
& Total & $36(33.3)$ & 97.2 & 35.0 & 18.1 & 51.7 & 8.0 & 38.7 \\
\hline
\end{tabular}


Table 1-2 Tooth DMF rates of newcomers in 1976 through 1981

\begin{tabular}{llccccccc}
\hline $\begin{array}{c}\text { Age } \\
\text { Years })\end{array}$ & Sex & $\begin{array}{c}\text { N } \\
\text { (Av. age) }\end{array}$ & $\begin{array}{c}\text { Personal } \\
\text { DMF } \\
\text { rate }(\%)\end{array}$ & $\begin{array}{c}\text { Tooth } \\
\text { DMF } \\
\text { rate }(\%)\end{array}$ & $\begin{array}{c}\text { Tooth } \\
\text { mortality } \\
\text { rate }(\%)\end{array}$ & $\begin{array}{c}\text { Tooth } \\
\text { fatality } \\
\text { rate }(\%)\end{array}$ & $\begin{array}{c}\text { Treated } \\
\text { tooth } \\
\text { rate }(\%)\end{array}$ & $\begin{array}{c}\text { Restora- } \\
\text { tive } \\
\text { index }\end{array}$ \\
\hline $6-14$ & Meles & $9(10.4)$ & 55.6 & 21.4 & 3.8 & 17.6 & 0.0 & 0.0 \\
& Females & $6(9.5)$ & 83.3 & 25.4 & 8.5 & 33.3 & 0.0 & 0.0 \\
& Total & $15(10.1)$ & 66.7 & 22.6 & 5.2 & 23.1 & 0.0 & 0.0 \\
\hline $15-19$ & Males & $61(17.0)$ & 96.7 & 25.2 & 3.4 & 13.3 & 13.9 & 61.6 \\
& Females & $43(17.2)$ & 95.3 & 31.4 & 6.2 & 19.7 & 16.9 & 63.1 \\
& Total & $104(17.0)$ & 96.2 & 27.8 & 4.5 & 16.3 & 15.2 & 62.2 \\
\hline $20-24$ & Males & $21(21.1)$ & 95.2 & 27.3 & 9.0 & 32.9 & 12.1 & 60.4 \\
& Females & $26(21.4)$ & 100.0 & 30.8 & 10.7 & 34.9 & 10.6 & 47.2 \\
& Total & $47(21.3)$ & 97.9 & 29.2 & 10.0 & 34.0 & 11.3 & 52.8 \\
\hline $25-29$ & Males & $17(27.1)$ & 100.0 & 24.4 & 8.9 & 36.5 & 8.4 & 49.3 \\
& Females & $14(27.0)$ & 100.0 & 44.7 & 16.7 & 37.4 & 21.0 & 62.4 \\
& Total & $31(27.1)$ & 100.0 & 33.6 & 12.4 & 37.0 & 13.8 & 57.1 \\
\hline $30-39$ & Meles & $11(34.2)$ & 90.9 & 34.7 & 23.1 & 66.4 & 2.5 & 16.7 \\
& Females & $10(33.8)$ & 100.0 & 49.5 & 29.5 & 59.6 & 10.3 & 36.4 \\
& Total & $21(34.0)$ & 95.2 & 41.7 & 26.1 & 62.6 & 6.0 & 28.6 \\
\hline $40-49$ & Meles & $2(42.5)$ & 50.0 & 35.7 & 35.7 & 100.0 & 0.0 & 0.0 \\
& Females & $4(43.0)$ & 100.0 & 25.9 & 10.7 & 41.4 & 13.0 & 76.5 \\
& Total & $6(42.8)$ & 83.3 & 29.2 & 19.0 & 65.3 & 9.6 & 76.5 \\
\hline
\end{tabular}

Table 1-3 Tooth DMF rates of newcomers in 1982 through 1988

\begin{tabular}{|c|c|c|c|c|c|c|c|c|}
\hline $\begin{array}{c}\text { Age } \\
\text { (Years) }\end{array}$ & Sex & $\stackrel{\mathrm{N}}{(\text { Av. age })}$ & $\begin{array}{c}\text { Personal } \\
\text { DMF } \\
\text { rate }(\%)\end{array}$ & $\begin{array}{c}\text { Tooth } \\
\text { DMF } \\
\text { rate }(\%)\end{array}$ & $\begin{array}{l}\text { Tooth } \\
\text { mortality } \\
\text { rate }(\%)\end{array}$ & $\begin{array}{c}\text { Tooth } \\
\text { fatality } \\
\text { rate }(\%)\end{array}$ & $\begin{array}{l}\text { Treated } \\
\text { tooth } \\
\text { rate }(\%)\end{array}$ & $\begin{array}{c}\text { Restora- } \\
\text { tive } \\
\text { index }\end{array}$ \\
\hline \multirow[t]{3}{*}{$6-14$} & Males & $10(10.0)$ & 70.0 & 19.7 & 0.7 & 3.4 & 6.2 & 32.1 \\
\hline & Females & $6(11.5)$ & 100.0 & 19.8 & 0.0 & 0.0 & 8.3 & 41.7 \\
\hline & Total & $16(10.6)$ & 81.3 & 19.8 & 0.4 & 1.9 & 7.1 & 36.5 \\
\hline \multirow[t]{3}{*}{$15-19$} & Males & $100(16.5)$ & 88.0 & 25.0 & 2.4 & 9.6 & 16.9 & 73.0 \\
\hline & Females & $50(16.6)$ & 92.0 & 29.3 & 4.5 & 15.3 & 16.7 & 64.3 \\
\hline & Total & $150(16.5)$ & 89.3 & 26.4 & 3.1 & 11.7 & 16.8 & 69.9 \\
\hline \multirow[t]{3}{*}{$20-24$} & Males & $30(21.4)$ & 93.3 & 31.7 & 5.4 & 16.9 & 17.2 & 62.0 \\
\hline & Females & $17(21.8)$ & 88.2 & 32.3 & 4.6 & 14.1 & 23.6 & 81.3 \\
\hline & Total & $47(21.5)$ & 91.5 & 31.9 & 5.1 & 15.9 & 19.6 & 69.2 \\
\hline \multirow[t]{3}{*}{$25-29$} & Males & $15(27.0)$ & 86.7 & 39.2 & 14.3 & 36.4 & 18.1 & 62.1 \\
\hline & Females & $6(27.2)$ & 100.0 & 43.3 & 15.9 & 36.6 & 11.6 & 35.6 \\
\hline & Total & $21(27.0)$ & 90.5 & 40.4 & 14.7 & 36.5 & 16.3 & 54.1 \\
\hline \multirow[t]{3}{*}{$30-39$} & Males & $26(35.3)$ & 100.0 & 53.2 & 31.6 & 59.4 & 21.0 & 66.5 \\
\hline & Females & $18(35.1)$ & 100.0 & 49.8 & 22.2 & 44.5 & 26.4 & 74.3 \\
\hline & Total & $44(35.2)$ & 100.0 & 51.8 & 27.8 & 53.6 & 23.3 & 70.1 \\
\hline \multirow[t]{3}{*}{$40-49$} & Males & $11(43.3)$ & 100.0 & 56.1 & 42.3 & 75.4 & 15.3 & 64.3 \\
\hline & Females & $11(42.9)$ & 90.9 & 48.5 & 27.8 & 57.3 & 19.2 & 67.2 \\
\hline & Total & $22(43.1)$ & 95.5 & 52.3 & 35.2 & 67.2 & 17.5 & 66.0 \\
\hline
\end{tabular}


Table 2 Comparison of tooth DMF rates with the Survey of Dental Disease by the Ministry of Health and Welfare Japan (MR/SMR ratio)

\begin{tabular}{lrcc}
\hline & $1971-1975$ & $1976-1981$ & $1982-1988$ \\
\hline Males & & & \\
Tooth DMF rate & $4.1168^{* * *}$ & -0.9970 & 0.8604 \\
Tooth mortality rate & $10.7888^{* * *}$ & $6.1429^{* * *}$ & $11.0220^{* * *}$ \\
Tooth fatality rate & $13.2150^{* * *}$ & $7.5832^{* * *}$ & $12.3968^{* * *}$ \\
Treated tooth rate & $-24.4009^{* * *}$ & $-8.3951^{* * *}$ & $-5.2219^{* * *}$ \\
Restorative index & $-20.0103^{* * *}$ & $-4.7448^{* * *}$ & -0.3632 \\
Females & & & \\
Tooth DMF rate & -1.2439 & $-3.2872^{* *}$ & $-4.6321^{* * *}$ \\
Tooth mortality rate & $17.2286^{* * *}$ & $8.1473^{* * *}$ & $7.5653^{* * *}$ \\
Tooth fatality rate & $20.8909^{* * *}$ & $10.2744^{* * *}$ & $9.5326^{* * *}$ \\
Treated tooth rate & $-34.3969^{* * *}$ & $-10.6621^{* * *}$ & $-11.0709^{* * *}$ \\
Restorative index & $-30.2747^{* * *}$ & $-5.1140^{* * *}$ & $-5.2995^{* * *}$ \\
\hline
\end{tabular}

${ }^{* *} \mathrm{p}<0.01^{* * *} \mathrm{p}<0.001$; Cells equal to or less than 5 subjects by subdivision were excluded from the test; Minus ratio neans index of this study is lower than that of the Survey

Table 3 Comparison in DMFT index of newcomers by sex (MR/SMR ratio)

\begin{tabular}{llll}
\hline & $1971-1975$ & $1976-1981$ & $1982-1988$ \\
\hline DT index & $-3.1603^{* *}$ & -0.8534 & -1.6461 \\
MT index & $-3.3842^{* * *}$ & $-2.4379^{*}$ & -0.6306 \\
F T index & $-2.8450^{* *}$ & -1.8426 & 0.1604 \\
\hline DMFT index & $-6.0241^{* * *}$ & $-2.2979^{*}$ & -0.4829 \\
\hline
\end{tabular}

${ }^{*} \mathrm{p}<0.05^{* *} \mathrm{p}<0.01{ }^{* * *} \mathrm{p}<0.001$; Minus ratio means higher index of females than males

に影慗され僅かに差がみられる（Table 3)。71-75年の 差は MT, DT, FT 指数全てが強く関与し，なかんうく MT 指数の関与が最も大きい。DMF 歯率関連の指数 でみた場合 DMF 歯率の差の推移には DMFT 指数の それにみられたのと同じ傾向を見て取ることができ， TMR の差の推移が連動している（Table 4)。しかし， TFR の差は大きくない。また，71-75，76-81年には処

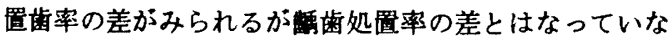
W。

\section{3. 重・最重度群と中等度群の能触䍜患の比较}

DMFT 指数とその各成分, DMF 歯率とそれに関連 する指数について男女別入所期別に IQ 程度別比較を行 った。71-75年入所の男の FT 指数に $5 \%$ 以下の危険率 で有意差を認める以外男女とも両群の DMFT 指数と その各成分に差を認めない (Table 5)。また, DMF 歯 率にも差を認めないが，71-75年に男女とも TMR，
TFR の差を，男に処膡歯率，触歯処膡率の差を認める。 その他にも若干の差は認められるがその意義は小さいと 思われる (Table 6)。

\section{4. 入所期による触䍜患の比較}

DMFT 指数とその各成分, DMF 歯率とそれに関連 する指数について男女別に入所期による比较を行った。 DMFT 指数は男女とも71-75年と76-81年，76-81年と 82-88年の間に差はみられないが FT 指数が大きく上が っている。しかし，女では76-81年と82-88年の間にはす でに FT 指数の差はみられない。DT 指数, MT 指数 はこれによって影製を受けていないように見えるがそれ でも71-75年と76-81年の女の DT 指数に僅か影響して いる。71-75年と82-88年の間では男女とも DT, FT 指 数の変化は大きく, 男の DMFT 指数が大きく上がって いる (Table 7)。DMF 粈率とそれに関連する指数から みた場合, 処固歯率, 䴣歯処圆率の上昇が71-75年と7681年, 76-81年と 82-88年，あるいは71-75年と 82-88年の 間で著明で，なおかつ，女では Table 7 に現れたと同 ヒく，76-81年と82-88年の間の差はなくなっている。ま た，男の76-81年と82-88年の間を除き TMR, TFR の 下降がみられる。DMF 齿率は男の76-81年と82-88年, あるいは71-75年と82-88年の間にだけ高度な差がみられ る (Table 8)。

\section{考察と結論}

我々は前報で精神発達遅滞者の DMFT 指数は日本 
Table 4 Comparison of tooth DMF rates in newcomers by sex (MR/SMR ratio)

\begin{tabular}{llcr}
\hline & $1971-1975$ & $1976-1981$ & $1982-1988$ \\
\hline Tooth DMF rate & $-12.2645^{* * *}$ & $-6.3019^{* * *}$ & -1.0686 \\
Tooth mortality rate & $-8.1215^{* * *}$ & $-3.9723^{* * *}$ & 0.3030 \\
Tooth fatality rate & $-2.5091^{*}$ & -0.8581 & 0.5071 \\
Treated tooth rate & $-5.8832^{* * *}$ & $-4.4408^{* * *}$ & -0.6843 \\
Restorative index & -1.0512 & -1.7169 & 1.6156 \\
\hline
\end{tabular}

${ }^{* *} \mathrm{p}<0.011^{* * *} \mathrm{p}<0.001$; Cells equal to or less than 5 subjects by subdivision were excluded from the test; Minus ratio means higher index of females than males

Table 5 Comparison in DMFT index of newcomers, categorized in profound to severe and moderate IQ groups (MR/SMR ratio)

\begin{tabular}{|c|c|c|c|c|c|c|}
\hline & \multicolumn{2}{|c|}{ 1971-1975 } & \multicolumn{2}{|c|}{$1976-1981$} & \multicolumn{2}{|c|}{ 1982-1988 } \\
\hline & Males & Females & Males & Females & Males & Females \\
\hline D T index & 0.5389 & 0.1907 & 0.1726 & 0.8894 & -0.9835 & -0.6803 \\
\hline$M T$ index & 1.7569 & 1.5704 & 0.8410 & 1.5465 & 0.5732 & 0.4077 \\
\hline F T index & $-2.5720^{*}$ & -1.6612 & -1.2077 & 1.6346 & -0.9600 & -0.7202 \\
\hline DMFT index & 0.1724 & -0.0647 & -0.5453 & 1.4441 & -0.0807 & -0.4946 \\
\hline
\end{tabular}

* $\mathrm{p}<0.05$; Minus ratio means index of moderate group is higher than that of profound and severe group

Table 6 Comparison of tooth DMF rates of newcomers, categorized in profound to severe and moderate IQ groups (MR/SMR ratio)

\begin{tabular}{lccc}
\hline & $1971-1975$ & $1976-1981$ & $1982-1988$ \\
\hline Males & & & \\
Tooth DMF rate & 0.3886 & 1.0503 & 0.9879 \\
Tooth mortality rate & $3.2694^{* *}$ & $2.4594^{*}$ & $2.7007^{*}$ \\
Tooth fatality rate & $3.5472^{* * *}$ & $2.2375^{*}$ & 1.8094 \\
Treated tooth rate & $-5.0197^{* * *}$ & -1.3995 & -1.3094 \\
Restorative index & $-5.1335^{* * *}$ & $-2.1815^{*}$ & -0.6410 \\
Females & & & \\
Tooth DMF rate & 0.7187 & -0.2124 & -0.2423 \\
Tooth mortality rate & $4.8543^{* * *}$ & -0.0854 & 1.4514 \\
Tooth fatality rate & $5.6147^{* * *}$ & 0.0197 & 1.9415 \\
Treated tooth rate & $-2.0078^{*}$ & 0.1292 & -1.0567 \\
Restorative index & -1.1209 & 0.5046 & -0.1897 \\
\hline
\end{tabular}

${ }^{*} \mathrm{p}<0.05^{* *} \mathrm{p}<0.01{ }^{* * *} \mathrm{p}<0.001$; Cells equal to or less than 5 subjects by subdivision were excluded from the test; Minus ratio means index of moderate group is higher than that of profound and severe group

人平均值に比して変わらず，また，MT 指数が過去に高 かったが現在ではほとんど差がなく，FT 指数は過去に 低かったが現在，改善方向にあると分析した9)。TMR， TFR の MR/S MR 比から判断すれば入所者の全被検歯,

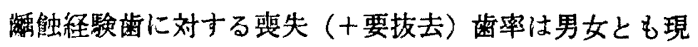

在に至るまで高く，処置歯率，歯処置率からみてむし

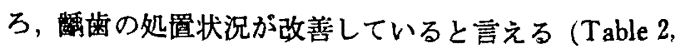
結果 1. 参照)。処圈率が上がって重症化が避けられ，婁 失斗の減少が次にもたらされるという図式を考えれば， これは妥当な所見で近い将来に舆失歯の減少を期待しう 
Table 7 Comparison in DMFT index, among periods of admission (MR/SMR ratio)

\begin{tabular}{|c|c|c|c|c|c|c|}
\hline & \multicolumn{2}{|c|}{$\begin{array}{c}1971-1975 \\
\text { and } \\
1976-1981 \\
\end{array}$} & \multicolumn{2}{|c|}{$\begin{array}{c}1976-1981 \\
\text { and } \\
1982-1988 \\
\end{array}$} & \multicolumn{2}{|c|}{$\begin{array}{c}1971-1975 \\
\text { and } \\
1982-1988 \\
\end{array}$} \\
\hline & Males & Females & Males & Females & Males & Females \\
\hline $\mathrm{DT}$ index & 1.7109 & $2.3631^{*}$ & 1.6110 & 0.7738 & $3.6727^{* * *}$ & $3.3820^{* * *}$ \\
\hline MT index & 0.6805 & 1.2194 & 0.2115 & 1.2739 & 0.9703 & $2.0367^{*}$ \\
\hline F T index & $-3.7894^{* * *}$ & $-3.3411^{* * *}$ & $-3.5627^{* * *}$ & -1.4866 & $-8.3337^{* * *}$ & $-4.4620^{* * *}$ \\
\hline DMFT index & -0.8174 & 0.4588 & -1.9024 & 0.1517 & $-3.6893^{* * *}$ & 0.6759 \\
\hline
\end{tabular}

${ }^{*} \mathrm{p}<0.05^{* *} \mathrm{p}<0.01{ }^{* * *} \mathrm{p}<0.001 ;$ Minus ratio means index of later newcomers is higher than that of earlier newcomers

Table 8 Comparison of tooth DMF rates, among periods of admission (MR/SMR ratio)

\begin{tabular}{lccc}
\hline & $\begin{array}{c}1971-1975 \\
\text { and } \\
1976-1981\end{array}$ & $\begin{array}{c}1976-1981 \\
\text { and } \\
1982-1988\end{array}$ & $\begin{array}{c}1971-1975 \\
\text { and } \\
1982-1988\end{array}$ \\
\hline Males & -0.4315 & $-4.6681^{* * *}$ & $-6.2186^{* * *}$ \\
Tooth DMF rate & $2.7385^{* *}$ & -0.5609 & $2.3510^{*}$ \\
Tooth mortality rate & $2.9737^{* *}$ & $2.1781^{*}$ & $5.7712^{* * *}$ \\
Tooth fatality rate & $-7.2250^{* * *}$ & $-6.6589^{* * *}$ & $-15.1720^{* * *}$ \\
Treated tooth rate & $-8.9254^{* * *}$ & $-5.1460^{* * *}$ & $-16.4862^{* * *}$ \\
Restorative index & & & 1.3282 \\
Females & 0.5364 & 0.9198 & $5.3662^{* * *}$ \\
Tooth DMF rate & $2.6159^{* *}$ & $2.8442^{* *}$ & $5.4640^{* * *}$ \\
Tooth mortality rate & $2.6870^{* *}$ & $2.7686^{* *}$ & $-7.4175^{* * *}$ \\
Tooth fatality rate & $-5.5229^{* * *}$ & -1.5804 & $-10.0790^{* * *}$ \\
Treated tooth rate & $-7.0889^{* * *}$ & $-1.9729^{*}$ & \\
Restorative index & & & \\
\hline
\end{tabular}

${ }^{*} \mathrm{p}<0.05^{* *} \mathrm{p}<0.01{ }^{* * *} \mathrm{p}<0.001$; Cells equal to or less than 5 subjects by subdivision were excluded from the test; Minus ratio means index of later newcomers is higher than that of earlier newcomers

る。検診時にM齔，F歯に関する判定を 誤る 例は少な

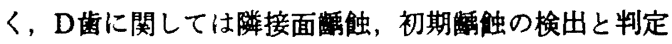
いかんでは検査者間にかなりの偏差を生ずる場合も想定 できる。かかる理由からM歯，F歯に関する指数につい てはかなり細かな比較は可能でも，日本人平均值との DMF 歯率の比較において厳格な判定は避けるべきであ ると思われるので㽢菌発生率ないし触繦験歯率に大き な開きはない（Table 2) と述べるにとどめたい。

71-75年には DMFT 指数にも各成分にも相当な男女 差がみられたにもかかわらず 76-81 年にはこれらの差は いちはやく解消のきさしを見せ，82-88年には霧消して いる (Table 3)。しかし,このことは入所者間の比較の 際かなりの時期まで性別に注意を要することを示唆して いる。Table 4 の諸指数の変摡 (結果 2 . 参照) からは

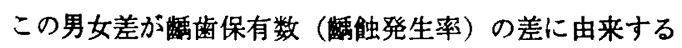

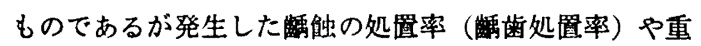
症化度（TFR）には差のないことが知られる。補足す れば，発生した皬触の進行に男女差はなく，治療を受け ることに対する消極性, 㮴極性にも男女差がないと解釈 できる。

精神発達遅滞の程度が的触瞒患の程度に影響するか否 かに関して 個人差を考虑した場合，施設入所が可能な 重・最重度と中等度の遅滞者の間の差は饃蝕発生率にお いて，処直率において，重症化度においてまったく見ら れない（Table 5)。個人差を排除し 2 集団間の総圌蝕発

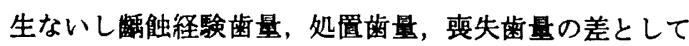
みた場合，幄滞程度の重い方が重症化して抜去にいたる 傾向が以前（71-75年）はみられ, 同時に, 処直歯率の差 が男にみられたが, 総酥蝕経験量の差すなわち DMF歯 率の差は終始みられない(Table 6)。二つの表から，精 
神発達荤滞の程度が触触䍜に影響するとしてもそれは 荤滞程度と触触の進行が相関するような本所的なもので はなく，歯科医療供給に左右される受動的なものである ことが考えられる。

年龄階䄲別一人平均被検齿数と DMFT 指数には入 所年度較差がなく，17年間にわたり踪触発生の変動がな かったと分析した9)。3期に分けた入所時期のうち，隣 合わせた 2 時期における DMFT 指数と DMF 歯率の 差は76-81年と82-88年に㧍ける男の DMF 齿率以外に は認められない (Table 7，8, 結果 4. 参照)。しかし, 71-75年と82-88年を比較した埸合，男では DMFT 指 数, DMF 歯率ともに差を認めるので男の場合, 触触発 生は17年の間，ごく㖃やかに増加してきたことが考えら れる。一見，䤍触発生に変化のないような，また女では 事実なかったが，このような状況の水面下では䴣歯の処

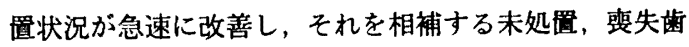
の減少があったはずである。

以上に述べてきたことは，施設入所が可能な程度の精 神発達遮滞者，すなわち，ある程度身辺自立のできた多 少は社会性のある精神発達遅滞者の触触䍜患社会経済 的因子を背景とする歯科医療の供給状況に影響される， と要約される。

\section{锝 辞}

本学齿学部小児齿科学教室 野田 忠教授，田辺義浩 研修医，小岩井均助手の温かい御援助に対し誌面をかり て心より勆意と敬意を表します。

またコロニーにいがた白岩の里 原 信郎所長はじめ

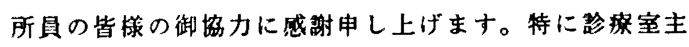
任 小林美恵子看護㧹，おなしく主任 竹内第子看護

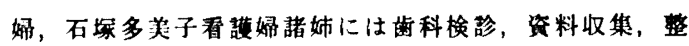
理に際し多くのお骨折りを頂いたことを菖き添え，合わ せて心より婮意を表します。

\section{文莘}

1) Brown, J. P. and Schodel, D. R. : A review of controlled surveys of dental disease in handicapped persons, J. Dent. Child., 43 ; 313320, 1976.

2) Tesini, D. A.: An annotated review of the literature of dental caries and periodontal disease in mentally retarded individuals, Spec. Care Dent., 1 ; 75-87, 1981.

3) Nowak, A. J. : Dental disease in handicapped persons, Spec. Care Dent., 4 ; 66-69, 1984.

4）小策法次，松沢智史，宮本房治，五味淵秀明， 曾我部微，網元受子：心身障害児における齿科 疫学的研究 第 1 報 身体発育ならびに而触䍜 患状況について，画学，66；672-685，1979.

5）五十栭清治, 伊藤総一郎, 上田量, 挥本和 夫：某美護学校におけるう触被患状況，東日本 齿学雑誌, $5: 59-68,1986$.

6）栗屋せつ子, 大森郁朗：重症心身障害児・者の 口腔管理に関する研究, 鹤見齿学, $3 ; 151-156$, 1977.

7) 岡田太㕷, 传野正之, 伊藤広明：重症心身障害 児の口腔内所見について，城齿大紀要，8； 209-214, 1979.

8）細矢由美子，松本史子，中村友美，後藤䈪治，

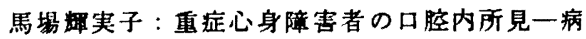
状並びに生活状態との関保一，小児画誌，23； 939-952, 1985.

9）小黒章, 堀井欣一：施設入所精神薄弱者の 䖵䍜患に関する程年疫学研究一入所時所見にっ いて一，口腔街生誌，39；684-692，1989.

10）水皇治夫：筒約統計学, 南江堂, 東京, 1988 , 92-94頁.

11）岛田義弘，前田博：菌科用㽞生統咶学，医齿 蒀出版, 東京, 1986, 15-16頁.

12) W. H. O.: Oral health surveys; basic methods, 2 nd ed., W. H. O., Geneva, 1977.

13）厚生省医務局掬科衙生課編：昭和 50 年齿科疾患 実態调查報告一㫗生省医務局调查一，医齿菓出 版, 1977 .

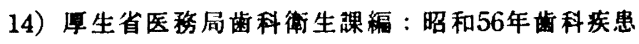
実態调查報告一厚生省医務局調查一，財団法人 口腔保健協会, 1983. 